\title{
Effect of substituting maize grain with cobs treated with combinations of urea and wood ash on chemical composition and in sacco degradability \\ ${ }^{1}$ Abdulazeez, A., ${ }^{2}$ Madibela, O. R. and ${ }^{2}$ Tsopito, C. M. \\ ${ }^{I}$ Federal College of Education (Technical) Gusau, Zamfara State, Nigeria \\ ${ }^{2}$ Department of Animal Science, Faculty of Animal and Veterinary Sciences, Botswana University of Agriculture and Natural Resources. \\ Gaborone, Botswana
}

Abstract

Corresponding author:azeezrazaq70@gmail.com

An experiment was conducted to determine the effect of substituting maize grain with maize cobs treated with 25\% urea (U) plus $75 \%$ wood ash (WA) on chemical composition and in sacco degradability. Maize grain was substituted with graded levels of 25U75WA in the dietary ingredients and the treatments were: $100 \mathrm{M}=100 \%$ maize grain, $66 \mathrm{M} 34 \mathrm{C}=66 \%$ maize grain plus $34 \%$ treated maize cobs, 34M66C $=34 \%$ maize grain plus $66 \%$ treated maize cobs and $100 C=100 \%$ treated maize cobs. Samples were analyzed for dry matter $(D M)$, organic matter $(O M)$, ash, crude protein $(C P)$, neutral detergent fibre $(N D F)$, acid detergent fibre $(A D F)$ and acid detergent lignin $(A D L)$; they were incubated in saccofor 6,12 , 24, 48 and $72 \mathrm{hrs}$ and their DM degradation kinetics described using the equation $y=a+b$ $\left(1-e^{-{ }^{c t}}\right)$. Results indicated that as maize grain is substituted with treated maize cobs, NDF, $A D F$ and $A D L$ also increased, however only the neutral detergent soluble (NDS) for treatment 100C was reduced. At 72 hrs of incubation, treatment 34M66C had the highest DM degradation, rapidly soluble fraction ' $a$ ' and potential degradability ' $a+b$ '. It was concluded that maize cobs treated with combinations of urea and WA could substitute $66 \%$ of maize grain in sheep diets.

Keywords: Maize cob, maize grain, In sacco, urea, wood ash

Effet de la substitution du grain de maïs par des épis traités avec des combinaisons d'urée et de cendre de bois sur la composition chimique et la dégradabilité du sac

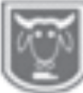

Résumé

Une expérience a été menée pour déterminer l'effet de la substitution du grain de maïs par des épis de maïs traités avec $25 \%$ d'urée (U) plus $75 \%$ de cendre de bois (WA) sur la composition chimique et la dégradabilité du sac. Le grain de maïs a été remplacé par des niveaux gradués de 25U75WA dans les ingrédients alimentaires et les traitements étaient : et 100C $=100 \%$ d'épis de maïs traités. Les échantillons ont été analysés pour la matière sèche (MS), la matière organique (MO), les cendres, les protéines brutes $(C P)$, les fibres au détergent neutre $(N D F)$, les fibres au détergent acide (ADF) et la lignine au détergent acide (ADL); ils ont été incubés dans sacco pour 6, 12, 24, 48 et 72 heures et leur cinétique de dégradation de la matière sèche décrite en utilisant l'équation $y=a+b(1-e-c t)$. Les résultats ont indiqué que lorsque le grain de maïs est remplacé par des épis de maïs traités, NDF, ADF et ADL ont également augmenté, mais que seul le détergent neutre soluble (NDS) pour le traitement 100C a été réduit. À 72 heures d'incubation, le traitement 34M66C présentait la plus forte dégradation de MS, la fraction rapidement soluble « $a$ » et la dégradabilité potentielle « $a+b$ ». Il a été conclu que les épis de maïs traités avec des combinaisons d'urée et d'AO pouvaient remplacer $66 \%$ des grains de maïs dans l'alimentation des moutons.

Mots clés : Epi de maïs, Grain de maïs, In sacco, Urée, Cendre de bois. 


\section{Introduction}

After burning of wood for domestic use or for other purposes, the ash left is alkaline which can be used to improve the digestibility of crop residues the same way as urea, however, itis available at household level at no cost to the farmer unlike the urea. Most researches have centered investigations on the use of either urea (Chenost, 1995) or wood ash (Ramirez et al.,1992; Solomon et al., 2012) as source of crop residue treatments but not their combinations. The combination is expected to reduce cost of treatment, improve digestibility at the same time incorporating both nitrogen present in urea and minerals from ash into the crop residue. After maize harvest and shelling of the grains, the cobs are left in the homestead as waste and in some cases burnt. Meanwhile livestock compete with man for grain, therefore there is need to conserve grains for human consumption by either partially or completely replacing it with urea-wood ash treated maize cobs which are rich in energy, nitrogen and minerals (Solomon et $a l ., 2012)$. This study was designed to assess the effect of substituting maize grain with cobs treated with combinations of urea and wood ash on chemical composition and in sacco degradability.

\section{Material and methods}

\section{Location of study, sample collection and treatment}

The study was conducted at the Botswana University of Agriculture and Natural Resources, Content Farm located $10 \mathrm{Km}$ north of Gaborone in South Eastern Botswana (24.59?'S25.94?E). Maize cobs treated with a combination of $25 \% \mathrm{U}$ and $75 \%$ WA were used to substitute graded level of maize grain in a complete diet as shown in Table 1.

\section{Laboratory analysis}

Dry matter (DM, ID number 930.15) for all samples were determined by drying in forced air oven at $60^{\circ} \mathrm{C}$ for $24 \mathrm{hr}$. Organic matter (OM, ID number 942.05) and ash were obtained by difference in weight after ignition at $550^{\circ} \mathrm{C}$ in a muffle furnace (Muffle Furnace Size 3, Gallenkamp, UK). The NDF, ADF and ADL were determined with ANKOM fiber analyzer (Ankom Technology Corporation, Fairport, NY, USA) according to the procedure of Van Soestet al, (1991). In the analysis of NDF, sodium sulphite and alpha amylase were also added. Nitrogen was determined by the Kjeldahl method (ID number 955.04) according to AOAC (1999) and CP determined as $\mathrm{N}^{*} 6.25$ (ID number 954.01 ).

\section{In sacco degradability}

The in saccoDM degradability analysis for the various treatments was carried out according to the procedure of Mehrez and Orskov (1977). Various samples were milled through a $3 \mathrm{~mm}$ sieve and $2 \mathrm{~g}$ weighed

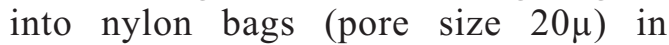
duplicates. These were then incubated for 6 , $12,24,48$ and 72 hours in two fistulated steers $(5$ treatments $\times 5$ time periods $\times 2$ fistulated steers). The procedure was repeated three times and means for each incubation used as replicates. The steers were fed commercial concentrate combined with crushed maize cobs for 5 days to get rumen microbes adapted to the feed. After removal, the nylon bags were thoroughly washed with cold running water until no further coloured liquid could be extruded, followed by drying at $60{ }^{\circ} \mathrm{C}$ for 48 hours. The dry matter losses for each incubation time were then determined according to the formula proposed by Osujiet al. (1993).

The DM degradation data were then fitted to the exponential equation $\mathrm{P}=\mathrm{a}+\mathrm{b}\left(1-\mathrm{e}^{-\mathrm{ct}}\right)$ (Orskov and McDonald, 1979): where $\mathrm{P}=$ DM disappearance in rumen at time't', $\mathrm{a}=$ the rapidly soluble fraction, $b=$ the insoluble but fermentable fraction, $\mathrm{c}=$ the constant rate of degradation of 'b' (\% per hour), $a+b=$ Potential degradability. ed $=a$ $+\mathrm{bc} /(\mathrm{c}+\mathrm{k})$ where $\mathrm{k}=$ the ruminal passage 
rate assumed at 3\% h.

\section{Statistical analysis}

In sacco degradability constants were generated with Non Linear Model (NLIN) SAS programme using the code of Osujiet al. (1993) and effects of treatment carried out using GLM procedure of SAS (2002) and means separated using Duncan's multiple range test (Steel and Torrie, 1984).

\section{Results}

Ingredients and chemical composition of experimental diet are shown in Table 1 . The result shows that the NDF, ADF and ADL of the experimental diets increased as the maize was substituted with urea-wood ash treated maize cobs; however, treatment $100 \mathrm{C}$ had the lowest NDS.

In sacco degradation characteristics of experimental feeds are shown in Table 2. Effect $(\mathrm{P}=0.0126,0.0126,0.01610 .0004$ and 0.0045 respectively) of treatments were observed at $6,12,24,48$ and $72 \mathrm{hrs}$ of incubation. Treatment 34M66C had the highest degradation at 6, 12, 24, 48 and 72 hrs of incubation $(32.59,35.91,41.96 \%$, 46.31 and 67.35 respectively) while treatments $100 \mathrm{M}, 66 \mathrm{M} 34 \mathrm{C}$ and $100 \mathrm{C}$ had similar degradability at those time periods. Treatments 100M and 66M34C had similar degradability at $72 \mathrm{hrs}$ of incubation (61.96 and $60.72 \%$ ) while treatment $100 \mathrm{C}$ had the least $(55.50 \%)$.

Table 1: Ingredients and chemical composition $(\mathrm{g} / \mathrm{kg})$ of experimental diet

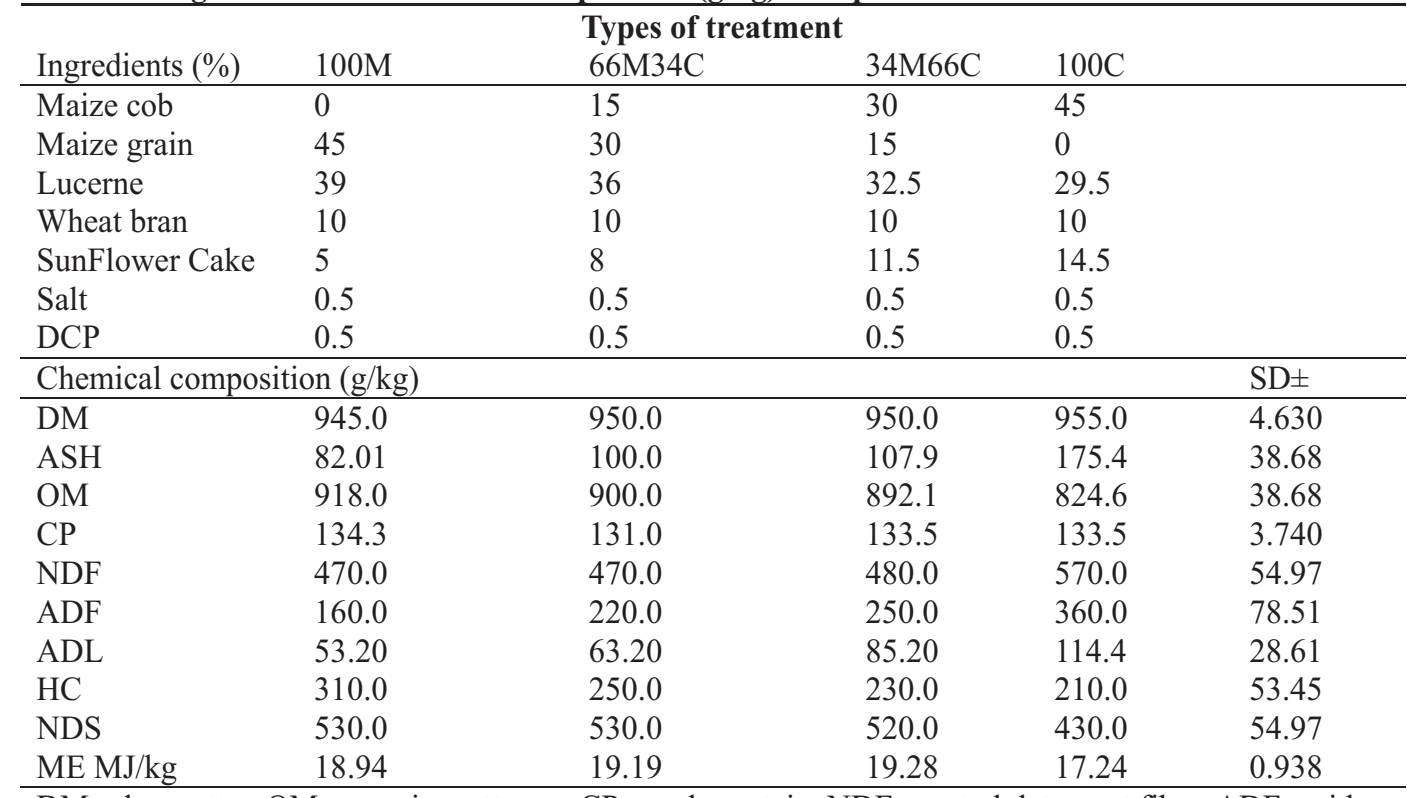

$\mathrm{DM}=$ dry matter, $\mathrm{OM}=$ organic matter, $\quad \mathrm{CP}=$ crude protein, $\mathrm{NDF}=$ neutral detergent fibre, $\mathrm{ADF}=$ acid detergent fibre, $\mathrm{ADL}=$ acid detergent lignin, $\mathrm{HC}=$ hemicellulose, $\mathrm{NDS}=$ neutral detergent soluble, $\mathrm{ME}=$ metabolizable energy, $\mathrm{DCP}=\mathrm{Di}$ calcium phosphate. $100 \mathrm{M}=100 \%$ maize, $66 \mathrm{M} 34 \mathrm{C}=66 \%$ maize $34 \%$ treated maize cobs, $34 \mathrm{M} 66 \mathrm{C}=34 \%$ maize, $66 \%$ treated maize cobs, $100=100 \%$ treated maize cobs, $\mathrm{SD}=$ Standard deviation . 
Table 2: In sacco degradation (\%) characteristics of experimental diets

\begin{tabular}{lcccccc}
\hline \multirow{2}{*}{$\begin{array}{l}\text { Incubation } \\
\text { time (hr) }\end{array}$} & \multicolumn{5}{c}{ Types of treatment } \\
& $100 \mathrm{M}$ & $66 \mathrm{M} 34 \mathrm{C}$ & $34 \mathrm{M} 66 \mathrm{C}$ & $100 \mathrm{C}$ & & \\
\cline { 2 - 5 } & & & & & & \\
\hline 6 & $27.21^{\mathrm{b}}$ & $27.85^{\mathrm{b}}$ & $32.59^{\mathrm{a}}$ & $26.16^{\mathrm{b}}$ & 0.9723 & 0.0124 \\
12 & $30.15^{\mathrm{b}}$ & $31.17^{\mathrm{b}}$ & $35.91^{\mathrm{a}}$ & $29.49^{\mathrm{b}}$ & 0.9725 & 0.0126 \\
24 & $37.67^{\mathrm{b}}$ & $39.01^{\mathrm{b}}$ & $41.96^{\mathrm{a}}$ & $36.53^{\mathrm{b}}$ & 0.8064 & 0.0161 \\
48 & $41.25^{\mathrm{c}}$ & $42.51^{\mathrm{b}}$ & $46.31^{\mathrm{a}}$ & $40.26^{\mathrm{c}}$ & 0.8778 & 0.0004 \\
72 & $61.96^{\mathrm{b}}$ & $60.72^{\mathrm{b}}$ & $67.35^{\mathrm{a}}$ & $55.50^{\mathrm{c}}$ & 1.633 & 0.0045 \\
\hline $100 \mathrm{M}=100 \%$ maize, $66 \mathrm{M} 34 \mathrm{C}=66 \%$ maize $34 \%$ treated maize cobs, 34M66C $=34 \%$ maize $66 \%$ treated \\
maize cobs, $100=100 \%$ treated maize cobs
\end{tabular}

In sacco degradation parameters ( $\mathrm{a}, \mathrm{b}, \mathrm{c}$, $\mathrm{a}+\mathrm{b}$ and ed) of experimental feed are shown in Table 3. There was effect $(\mathrm{P}=0.0523)$ of treatment on the rapidly soluble fraction 'a'. Treatment 34M66C had the highest ' $\mathrm{a}$ ' fraction $(30.76 \%)$ while the rest of the treatments had similar 'a' fractions. Effect $(\mathrm{P}=0.6605)$ of treatments was not observed on rate of degradation ' $\mathrm{c}$ ' while effect $(\mathrm{P}=$ $0.0064)$ of treatments was observed on potential degradability ' $\mathrm{a}+\mathrm{b}$ ' and effective degradability 'ed' $(\mathrm{P}=0.0083)$. Treatment $34 \mathrm{M} 66 \mathrm{C}$ had the highest ' $\mathrm{a}+\mathrm{b}$ ' $(85.82 \%)$ while the rest of the treatments were similar. Treatment 34M66C also had the highest 'ed' $(43.83 \%)$ while treatment $100 \mathrm{C}$ had the least $(36.91 \%)$. Treatments $100 \mathrm{M}$ and $66 \mathrm{M} 34 \mathrm{C}$ had similar 'ed' (40.23 and $40.31 \%)$.

Table 3: In sacco degradation (\%) parameters of experimental diets

Types of treatment

\begin{tabular}{|c|c|c|c|c|c|c|}
\hline \multirow[t]{2}{*}{ Parameters } & $100 \mathrm{M}$ & $66 \mathrm{M} 34 \mathrm{C}$ & $34 \mathrm{M} 66 \mathrm{C}$ & $100 \mathrm{C}$ & \multirow[b]{2}{*}{ SE } & \multirow[b]{2}{*}{ P value } \\
\hline & & & & & & \\
\hline A & $27.72^{\mathrm{b}}$ & $27.50^{\mathrm{b}}$ & $30.76^{\mathrm{a}}$ & $26.14^{b}$ & 0.7015 & 0.0523 \\
\hline B & $52.86^{\mathrm{ab}}$ & $52.35^{\mathrm{ab}}$ & $55.06^{\mathrm{a}}$ & $51.47^{\mathrm{b}}$ & 0.6015 & 0.1597 \\
\hline $\mathrm{C}$ & 0.0093 & 0.0097 & 0.0094 & 0.0079 & 0.0005 & 0.6605 \\
\hline$a+b$ & $80.58^{b}$ & $79.85^{\mathrm{b}}$ & $85.82^{\mathrm{a}}$ & $77.61^{b}$ & 1.172 & 0.0064 \\
\hline $\mathrm{Ed}$ & $40.23^{b}$ & $40.31^{b}$ & $43.88^{\mathrm{a}}$ & $36.91^{\mathrm{c}}$ & 0.9586 & 0.0083 \\
\hline
\end{tabular}

$100 \mathrm{M}=100 \%$ maize, $66 \mathrm{M} 34 \mathrm{C}=66 \%$ maize $34 \%$ treated maize cobs, $34 \mathrm{M} 66 \mathrm{C}=34 \%$ maize $66 \%$ treated maize cobs, $100=100 \%$ treated maize cobs, $a=$ rapidly soluble fraction, $b=$ insoluble but fermentable fraction, $\mathrm{c}=$ degradation rate $\mathrm{h}, \mathrm{a}+\mathrm{b}=$ potential degradability, ed $=$ effective degradability, $\mathrm{SE}=$ standard error.

\section{Discussion}

It was observed that the more the substitutions of maize grain with treated maize cobs, the more the ash content of the feed. The high amount of ash in the feed may supply more minerals to the animals and rumen microbes (Imbeah, 1999). However, the substitution also led to increase in $\mathrm{NDF}, \mathrm{ADF}$ and $\mathrm{ADL}$ and reduction in NDS of treatment 100C. The higher NDS content of treatments $100 \mathrm{M}$, 66M34C and 34M66C could be attributed to their maize contents that were mostly cell soluble compared to treatment $100 \mathrm{C}$ that was characterized by higher contents of NDF, ADF and ADL which can negatively affect digestibility. Various authors have also reported increases in NDF, ADF and 
ADL contents of feeds when energy source is substituted with maize cobs (Khan et al., 2006; Wanapatet al., 2012). The reason for the high NDF and ADF contents of treatment $100 \mathrm{C}$ based diet was because of its high crude fibre content.At 72 hours of in sacco degradability, treatment 34M66C had the highest percent degradability probably because it had better colonization and attachment by rumen microbes due to its low maize grain contents compared to treatments $100 \mathrm{M}$ and 34M66C. When diets have high grain contents, they are fermented rapidly by rumen microbes to VFAs which leads to a drop in rumen $\mathrm{pH}$. A drop in rumen $\mathrm{pH}$ depresses the activities of rumen microbes thereby impacting negatively on digestibility of fibrous materials. However, the impact of low $\mathrm{pH}$ may not be significant under in sacco condition due to dilution resulting from entry and exit of other particles surrounding the nylon bags. The fact that treatment 34M66C had the highest degradation (\%) after 72 hours of incubation and highest potential degradability ' $a+b$,' implied that it was superior to the other treatments in terms of digestibility. Carroet al. (1991) reported that the fraction that would be degraded when samples were incubated indefinitely in the rumen was the potential degradability and did not indicate the in vivo condition. Khazaalet al. (1995) reported that potential degradability of feed pointed to the quality of feed because it was associated with the degradability of feed. Therefore, feeds with higher ' $a+b$ ' fractions may degrade faster than those with lower ' $a+b$ ' fractions.

\section{Conclusion}

This study revealed that $66 \%$ of maize cobs treated with a combination urea and wood ash could replace maize grain in sheep diets.

\section{Acknowledgement}

Tertiary Education Trust Fund (TETFUND) Abuja, Nigeria, is acknowledged for sponsorship of the research work.

\section{References}

AOAC, 1999. Official Methods of Analysis, $16^{\text {th }}$ ed. Official Methods of Analysis of AOAC International, Gaithersburg, MD, USA.

Carro, M.D., Lopez, S., Gonzalez, J.S. and Ovejero, F.J. 1991. The use of the rumen degradation characteristics of hay as predictors of its voluntary intake by sheep. Animal Production 52: 133-139.

Chenost, M. 1995. Optimizing the Use of Poor Quality Roughage through Treatments and Supplementation in Warm Climate Countries with Particular EmpHasis on Urea Treatment. First Electronic Conference on Tropical Feeds with Particular EmpHasis on Urea Treatment FAO, Rome.

Imbeah, M. 1999. Wood ash as mineral supplement for growing lambs under village conditions in the tropics Small Ruminant Research 32: 191-194.

Khan, M.A., Iqbal, Z., Sarwar, M., Nisa, M., Khan, M. S., Lee, W.S. and Kim, H.S. 2006. Urea treated maize cobs ensiled with or without additives for buffaloes: Ruminal characteristics, digestibility and nitrogen metabolism Asian-Aust. J. Anim. Sci. 5: 705- 712.

Khazaal, K., Dentinho, M.T., Robeiro, J.M. and Orskov, E.R. 1995. Prediction of apparent digestibility and voluntary intake of hays fed to sheep: comparison between using fibre components, in vitro digestibility or characteristics of gas production or nylon bag degradation. Anim. Sci.61: 527538.

Mehrez, A.Z. and Orskov, E.R. 1977. A study of the artificial fibre bag 
technique for determining the digestibility of feeds in the rumen. J. Agric. Sci.88: 645-650.

Orskov, E.R. and McDonald, L.M. 1979. The estimation of protein degradability in the rumen from incubation measurement weighted according to rate of passage. J. Agric. Sci.Camb. 92: 499-503.

Osuji, P.O., Nsahlai, I.V. and Khalili, H. 1993. Feed evaluation. ILCA Manual 5 ILCA ( international Livestock Centre for Africa), Addis Ababa, Ethiopia. pp40.

Ramirez, R.G., Cruz, F. and Gonzalez, C.C. 1992. Effect of treating corn stover with wood ash and sodium hydroxide on nutrient digestibility by sheep and goats Small Ruminant Research 7: (3) 225-233.

SAS, 2002. Statistical Analysis System. SAS user's guide: Statistics, SAS Inst. Inc., Carry, NC.
Solomon, A. K., Ulfina, G.G. and Gemeda, D. J. 2012. The potential of treatment with ash solution in improving degradability of fibrous feeds in Ethiopia. Agric. Sci. Res. J. 3:100- 105 .

Steel, R.G.D. and Torrie, J.H. 1984. Principles and Procedures of Statistics. A Biometrical Approach $\left(2^{\text {nd }}\right.$ Ed). McGraw Hill Book Co. Inc. New York. USA.

Van Soest, P.J., Robertson, H.B. and Lewis, B.A. 1991. Methods of dietary fibre, NDF and non-starch polysaccharides in relation to animal material. J. Dairy Sci. 74: 3583-3595.

Wanapat, M., Pilajun, R., Kang, S., Satyaningsih, K. and Setyawan, A.R. 2012. Effect of ground maize cobs replacement for cassava chip on feed intake, rumen fermentation and urinary derivatives in swamp buffaloes. Asian-Aust. J. Anim. Sci. 8: 1124-1131.

Received: $8^{\text {th }}$ June, 2021 Accepted: $27^{\text {th }}$ September, 2021 